\title{
Urban residents and their preferences of environmental elements
}

\author{
A. C. Kasim, M. U. Azizan, K. Hussin \& M. M. G. M. A. Rahman \\ Department of Real Estate, Faculty of Geoinformation and Real Estate, \\ Universiti Teknologi Malaysia, Malaysia
}

\begin{abstract}
Densification is recommended to achieve urban sustainable development through road and building construction as well as expanding environmental elements. Continuously, the urban areas increase in the number of inhabitants as well as in size. An urban environmental element provided by urban green spaces, water bodies and good environmental quality create the economic and recognized the positive impacts to the surrounding property. Generally, people seem to be able to appreciate the natural and designed landscape as well as the recreational benefits. However, speedy urbanization process overwhelmed the living space thus incur the damage in social relationships. The land use pressures are interrelated internally for fiscal benefits and externally for creating the preserve land for habitat. For urban residents, the creation, preservation and maintenance of urban environmental elements and greened areas must be considered along with the other essential services as we move into the rapid growth of urbanization. Unfortunately, such environmental elements are too often the first budget item cut when there are trade-offs to be made. Accordingly, this research is conducted through quantitative method by distributing the questionnaire to residents in an urban area in order to gather information on the preferences of residents about the urban environmental elements specifically. This study is expected to reveal all of the aspects that have to be collectively considered in expanding the benefits of urban environmental elements as well as to show the connections that can influence a city's image and urban planning positively.

Keywords: urban environmental element, urban green space, water body, residents, preference.
\end{abstract}




\section{Introduction}

Urban sustainable development has become an essential agenda in this country. Fundamentally, densification is a recommended tool to achieve urban sustainable development through appropriate planning and innovation. An area developed with roads and buildings construction as well as expanding the urban environmental elements especially in the residential area is part and parcel of the action taken. One of the initiatives from the vital sector was by providing the natural urban environmental element and initiates the green element such as urban green space and water body. These two elements of natural urban environmental element provide amenities and services that contribute fundamentally to the quality of urban life $[1,2]$.

These urban environmental elements could create economic and positive impacts to the surrounding. It contributed $7.1 \%$ and $13.2 \%$ raise in housing price respectively due to view of green spaces and the proximity to the water [3]. It has been obligatory prepared by government in any development implemented especially for the residential development area. It has also been promoted by legal instrument and development guidelines prepared by the planning authority. Moreover, different approach taken such as promoting the legal framework to the states [4]. This is due to the fact that the environmental element has required that habitat networks cover a minimum of $10 \%$ of the total land area of multifunctional benefits in terms of social benefit (health and wellbeing's, recreational and educational value), economic benefits (economic value) as well as environmental response includes (biodiversity, ecological, improved air quality) [5].

In Malaysia, development guidelines and procedure basically prepared for the provision of natural and designed urban environmental element to achieve sustainable and safe city. Besides, the three (3) main pillars described by the National Policy on the Environment were the sustainable development, economic, social and cultural progress as well as the enhancement of quality of life and the environment [6]. Currently, urban residents seem to be able to appreciate the natural and understand as well as respect the strong spiritual values that associated with natural environment [7]. The characteristics of the urban green elements underpin the functioning of urban ecosystem. Urban green space such as public parks and green landscape play an important role in supporting ecosystem services and biodiversity in the urban area [8]. These elements provide the primary contact and relations involved between the people and the environment [3, 8]. They also may influence the physical and mental well-being of these people [9, 10], and promote social benefits as for meeting places in case for public green spaces $[2,11]$.

The current literature on urban environmental element discussed the needs and its benefits in terms of social, economic and environment basically to attain higher quality of life. It prominently focused on the benefits of the urban environment for the purpose of sustainable development $[8,12,13]$, to attain the sense of belonging $[2,14]$, to achieve the optimum in physical and mental health, to create the social interaction and social well-being among urban residents $[15,16]$ to maintain the recreation spaces [17], to minimize crime opportunity $[18,19]$ and as habitat to 
several species of birds, insects and air quality [19]. Besides direct effect on the environmental aspects, research was also conducted on the social value for aesthetic experience and historical value [2, 19] and scenery [20].

Nevertheless, despite of these benefits, due to speedy urbanization process overwhelmed the living spaces and urban green spaces were disappearing and increasingly becoming scarce [21]. The land use pressures are interrelated internally for fiscal benefits and externally for creating the preserve land for habitat. For urban residents, the creation, preservation and maintenance of urban environmental elements and greened areas must be considered along with the other essential services as we move into the rapid growth of urbanization. Unfortunately, such environmental elements are too often the first budget item cut when there are trade-offs to be made. In concern of this situation, thus the primary goal of this study is to conducts a survey on residents in urban area in order to gather information on the provision of the urban preferences either urban green space or water body were needed. This study is expected to reveal all of the aspects that have to be collectively considered in the expanding the benefits of urban environmental elements as well as to show those connections that can influence the city's image and urban planning positively.

\section{Review of literature}

The urban environmental elements were also referred as urban environmental amenity [21, 22]. Basically, the significance of the urban environmental elements provides the intangible benefits that contribute to the quality of life [2] such as social, ecological and health [23]. Moreover, with the presence of education and environmental awareness, the demand for urban natural as well as the environmental resources are growing gradually especially in developing countries [3]. Therefore, the important presence and adequate management of the environmental element area was very crucial. The element of the urban environment amenity was included in the green space [3, 21, 22], water bodies [3, $21,22]$ and others. In addition, those other few amenities included that are bestowed by nature are the only true exceptions and these would be things such as natural weather, natural water routes, natural topography and natural views [24]. The designated urban environmental elements provide amenities to the urban residents. The environmental element also included water features [9], trees [9, $25]$, street [23], park [3, 10, 26] and botanical garden [3, 26] greenway $[2,4,11]$ and stream corridor [18].

The urban environmental elements conservation and preservation has been recognized as the primary needs along with the rapid urbanization and improvement of the planning diversity of an urban [23]. Moreover, these urban utilities provide space for the social and economic aspects and the expression of diversity in both cultural and social [23]. Furthermore, the numerous aspects of physical and subjective features and design of the urban environmental elements affect the residential property. For instance, the amenity value contributes to $7.1 \%$ and $13 \%$ increment for view for green spaces and the proximity to the water bodies respectively [3]. Besides, the physical characteristics of the urban environmental 
element directly influenced the preferences and the willingness to pay of the propose investment and participant for investment in green infrastructure [12].

Additionally, the urban environmental element is a vital part with set of function which can provide the interaction spaces between residents [23]. The designated open space provides amenities to residents in the form of recreational benefits [27]. For instance, it does create the sense of belonging by the atmosphere of the green neighbourhood $[2,14,28]$, physical and mental health $[9,23]$ as the element could affect the emotional feeling [29] and get rid of the pressure of urban life [26]. In addition, the green spaces contributed to community quality of life through health and fitness [2]. The urban green elements provide the recreational opportunity [4] as well as the area [18] and amenities [4] for family to enjoy the urban experience $[2,11,18,23]$. Besides providing a place for walking or sitting out, these elements can be venues for different activities from outdoor eating to street entertainment sports [23]. In addition, the environmental elements also create the historical [19] and aesthetic value [2, 30]. Indirectly, these urban environmental elements were also recognized as the area to preserve habitat animal such as birds and insect's species [19].

The contribution of these urban environmental elements is indeed undeniable. The element used for social interaction medium and connecting people [11] to meet and chat with others in the park [26]. Based on survey, park is place in which the majority respondents to better socialize [31]. Besides, the different activities were benefited from the urban environmental element for different status and age. The young ages prefer to meeting and sporting whiles the adult and elderly into contemplating with the nature [32]. Indirectly, the characteristics of the water sources have created the beautiful scenery to the ambience and the "openness" pleasures the residents within view [20]. Indeed, the intangible benefits from these urban environmental elements provide public with privacy needs $[14,26]$. The proximity to the element such as water body of a city and green spaces raised housing prices by about $10 \%$ and $2 \%$ respectively [22]. For instance, perceived proximity to nature contributes to the sense of belonging, satisfaction and comfort [28] and human wellbeing [11]. Apart from that, based on [26], the view and visual elements of a park was the main reason user to do activity. In facts, the main factors accounting for residents' perception towards stream corridors were for recreational use, nature and scenery [18]. The urban green spaces specifically decrease the air pollution and provide function as the security element by protect and prevent direct view thru the surroundings of the residential compounds [19]. Besides, the quality and the safety level and physical condition of the urban environmental element were one of the factors that attract people to visit the area [18]. Hence, the proximity to water also contributed to the users' satisfaction [26] and the easy access to the nature from their homes as well as the cleanliness considered as the primary reason to visit the green amenity $[18,20]$.

Regarding the benefits bestowed upon the urban environmental to the economic benefits, the conservation and preservation of these element has been widely recognized by governments and other parties especially in planning and development of an area. The government could take the significant scope of enhancing government controlled collector rate of urban residential property in 
areas near to these environmental elements [22]. Thus, could be ploughed back in conservation effort to expand the urban environmental spaces in the city [22]. In some new and planned cities, the provisions for creation of urban parks/ garden and water bodies were prepared due to create support in order to minimize the environmental issues as well as to create the healthy living environment in the city [33]. Hence, the old and new residential areas have different environment reflecting underlying different in land use and provisions patterns in urban forms [34]. In order to meet life satisfaction and quality of life, the existence of these urban green environmental elements are important with about $70 \%$ of Malaysia's population living in towns and cities and the urbanization is still ongoing [35]. Furthermore, the growth of urbanism and urban living has become a way of life and a key element in Malaysia's civilization and others developed country.

In conjunction with the roles of several responsible parties, the significant part is to include the participation of the public when it comes to decision making [17]. The preference and the public participation is to assess the environmental factors which make a location attractive to live in, particularly, in a planned city of developing country as well as to assist the urban land use planning with emphasis on urban nature conservation like green spaces and water bodies [22] as well to integrate the urban development and pricing of related services [21]. Some aspects of urban environmental element like "quality air" or "safety" are desirable to all communities in all urban areas due to different idea within the communities. The variation of definition and perspective makes defining the urban environmental such a challenge. However, the defining and enlightenment these elements are important in order to consulting the community to learn what urban element means to the people live in the urban environment. In the next section, urban community understanding on urban environmental element such as urban green spaces and water body are examined. Later, this understanding would lead to the potential selection and preferences between urban green spaces or water body in the selected case area.

\section{Results and discussion}

This paper aimed to gather information on urban resident's preferences to the need of either urban green space or water body. The data are analyzed using descriptive statistics such as frequency and percentage that will justify the selection and the residents' preferences about the urban green space and water body. A survey was carried out using questionnaires to gather information and perception based on key benefits about the urban environmental elements. A total number of 220 questionnaires were distributed to residents asking their preferences on the benefits of the urban green space and water body. The item to discover the urban residence preferences based on the three (3) domains of the benefits, physical conditions and value.

The survey was conducted in Johor Bahru area in three (3) different local authorities namely Johor Bahru City Council, Johor Bahru Tengah Municipal Council and Pasir Gudang Municipal Council. 200 out of the 220 completed questionnaires were analyzed. The resident's selection and preferences between 
urban green space and water body were based on the contribution from the three (3) domains (benefits, physical and value) are listed in the following Table 1.

Table 1: Frequency analysis for residents' preference on urban green space and water body.

\begin{tabular}{|c|c|c|c|c|c|}
\hline \multirow{2}{*}{ Domain } & \multirow{2}{*}{ Items } & \multicolumn{2}{|c|}{ Green space } & \multicolumn{2}{|c|}{ Water body } \\
\hline & & $n$ agreed & $\%$ & $n$ agreed & $\%$ \\
\hline \multirow[t]{7}{*}{ Benefits } & $\begin{array}{l}\text { Mental/physical } \\
\text { health }\end{array}$ & 93 & 46.5 & 80 & 40 \\
\hline & Security & 62 & 31 & 60 & 30 \\
\hline & Well-being & 108 & 54 & 79 & 39.5 \\
\hline & Privacy & 85 & 42.5 & 68 & 40 \\
\hline & $\begin{array}{l}\text { Recreational/ } \\
\text { activity }\end{array}$ & 80 & 40 & 86 & 43 \\
\hline & View & 85 & 42.5 & 66 & 33 \\
\hline & $\begin{array}{l}\text { Social } \\
\text { interaction }\end{array}$ & 92 & 46 & 92 & 46 \\
\hline \multirow[t]{6}{*}{ Physical } & Proximity & 91 & 45.5 & 68 & 34 \\
\hline & Size/area & 78 & 39 & 79 & 39.5 \\
\hline & Accessibility & 48 & 24 & 41 & 20.5 \\
\hline & Cleanliness & 71 & 35.5 & 60 & 30 \\
\hline & Safety & 76 & 38 & 54 & 27 \\
\hline & Maintenance & 64 & 32 & 65 & 32.5 \\
\hline \multirow[t]{2}{*}{ Value } & Aesthetic & 80 & 40 & 62 & 31 \\
\hline & $\begin{array}{l}\text { Sense of } \\
\text { belonging }\end{array}$ & 101 & 50.5 & 101 & 50.5 \\
\hline
\end{tabular}

$n$ - Total residence

According to the scale of strongly disagreed, disagreed, neutral, agreed and extremely agreed, results explored the residences' preferences based on the listed items. The "agreed" and "extremely agreed" were considered as the value to be referred as the more preference elements by the residence whichever is higher. It can be seen clearly in Table 1 that urban green spaces were preferred more as the contribution to the well-being of the community. While, the water body agreed and more preferable due to benefited for recreational space and activity availability. Apparently, the importance level of the urban green space and water body were gathered based on the analysis factors to be considered when purchasing a residential property. As the result, the importance level of the green space appeared as 50\% very important element to be considered compared to $39 \%$ very important for water body to purchase a house (refer to Figure 1).

The benefits listed in Table 1 represent the needs and intangible benefits of the urban environmental element to urban residents. It shows that this widely benefits community in different aspect consist of direct and indirect benefits, physical 
benefits and the value. These benefits will be the reason for the government and others planners as well as developers that are involved in residential development to provide a sufficient urban environmental element especially the urban green space and water body.

\begin{tabular}{|} 
Land area (44.5\% very important) \\
Main F. Area (47\% important) \\
Anc. area (47\% very important) \\
Type of house (45\% very important) \\
Age of the building (42\% very important) \\
Number of bedrooms (39\% important) \\
No. of bathrooms (41.5\% important) \\
Tenure (44.5\% very important) \\
Prox. to city centre (42\% very important) \\
Location (52.5\% very important) \\
Bank lending rate (51\% very important) \\
Grant/doc. of title (54\% very important) \\
Green area (50\% very important) \\
Water body (39\% very important) \\
Land status (53\% very important)
\end{tabular}

Figure 1: The importance level of urban green space and water body factors to be considered when buying residential property.

\section{Conclusion}

Very few studies are available involving the valuations of urban environmental element in developing countries including Malaysia. The quantification and evaluation of urban environmental, social and economic benefits of the element remained a difficult task. The urban environmental elements included urban green space and water body, however affect the perspectives of the residents on residential price. Parties involved development sector always struggle in financing the urban nature conservation projects. Attempts were made in this study to establish at least the information regarding the choice been made by the urban residential between urban green space and water body. It is also to serve municipalities with different perspectives in order to provide and generate sufficient revenue to further consolidate urban nature element and provide better quality of life and recreational/leisure opportunities to the urban citizens. It is expected that the results of the present study will boost future extensive research about the economics of urban environmental element in Malaysian cities. 


\section{References}

[1] Van Herzele, A., \& Wiedemann, T. (2003). A monitoring tool for the provision of accessible and attractive urban green spaces. Landscape and urban planning, 63(2), 109-126.

[2] Shafer, C. S., Lee, B. K., \& Turner, S. (2000). A tale of three greenway trails: user perceptions related to quality of life. Landscape and urban planning, 49(3), 163-178

[3] Jim, C. Y., \& Chen, W. Y. (2006). Impacts of urban environmental elements on residential housing prices in Guangzhou (China). Landscape and Urban Planning, 78(4), 422-434.

[4] Von Haaren, C., \& Reich, M. (2006). The German way to greenways and habitat networks. Landscape and urban planning, 76(1), 7-22.

[5] Molla, M.B (2015). The Value of Urban Green Infrastructure and Its Environmental Response in Urban Ecosystem: A Literature Review.

[6] National Policy on the Environment (2002), Ministry of Science, Technology and Environment, Malaysia from http://www.doe.gov.my/portalv1/wp-content/uploads/2013/01/dasar_alam sekitar_negara.pdf on July 24th, 2016.

[7] Schroeder, H. W. (1992, April). The spiritual aspect of nature: A perspective from depth psychology. In Proceedings of the 1991 Northeastern Recreation Research Symposium (pp. 25-30). G. Vander Stoep.

[8] Barbosa, O., Tratalos, J. A., Armsworth, P. R., Davies, R. G., Fuller, R. A., Johnson, P., \& Gaston, K. J. (2007). Who benefits from access to green space? A case study from Sheffield, UK. Landscape and Urban Planning,83(2), 187-195.

[9] Naderi, J. R., \& Raman, B. (2005). Capturing impressions of pedestrian landscapes used for healing purposes with decision tree learning. Landscape and Urban Planning, 73(2), 155-166.

[10] Gobster, P. H. (1998). Urban parks as green walls or green magnets? Interracial relations in neighborhood boundary parks. Landscape and urban planning, 41(1), 43-55. Roslina Sapawi (2009). Urban Heat Island Mitigation through Green Roof Technology. Sarjana Pengurusan Persekitaran. Fakulti Kejuruteraan Awam, Universiti Teknologi Malaysia. THESIS

[11] Tan, K. W. (2006). A greenway network for Singapore. Landscape and urban planning, 76(1), 45-66.

[12] Mell, I. C., Henneberry, J., Hehl-Lange, S., \& Keskin, B. (2013). Promoting urban greening: Valuing the development of green infrastructure investments in the urban core of Manchester, UK. Urban forestry \& urban greening, 12(3), 296-306.

[13] Ward, C. D., Parker, C. M., \& Shackleton, C. M. (2010). The use and appreciation of botanical gardens as urban green spaces in South Africa. Urban Forestry \& Urban Greening, 9(1), 49-55.

[14] Simson, A. J. (2000). The post-romantic landscape of Telford New Town.Landscape and urban planning, 52(2), 189-197. 
[15] Foltete, J. C., \& Piombini, A. (2007). Urban layout, landscape features and pedestrian usage. Landscape and Urban Planning, 81(3), 225-234.

[16] Velarde, M. D., Fry, G., \& Tveit, M. (2007). Health effects of viewing landscapes-Landscape types in environmental psychology. Urban Forestry \& Urban Greening, 6(4), 199-212.

[17] Arnberger, A., \& Eder, R. (2012). The influence of green space on community attachment of urban and suburban residents. Urban Forestry \& Urban Greening, 11(1), 41-49.

[18] Asakawa, S., Yoshida, K., \& Yabe, K. (2004). Perceptions of urban stream corridors within the greenway system of Sapporo, Japan. Landscape and urban planning, 68(2), 167-182.

[19] Yokohari, M., Amemiya, M., \& Amati, M. (2006). The history and future directions of greenways in Japanese New Towns. Landscape and Urban Planning, 76(1), 210-222.

[20] Austin, M. E. (2004). Resident perspectives of the open space conservation subdivision in Hamburg Township, Michigan. Landscape and Urban Planning, 69(2), 245-253.

[21] Gupta, V., Mythili, G., \& Hegde, D. S. (2009). Deriving implicit prices for urban environmental amenities from Mumbai housing prices: a revealed preference approach. In First International Conference on Landscape Economics, Vienna.

[22] Chaudhry, M. P., Singh, G., \& Arun Bansal, P. (2013). Valuation of Urban Environmental Amenities in Developing Countries: A Case Study from Chandigarh, India. Global Journal of Science Frontier Research, 13(2).

[23] Thompson, C. W. (2002). Urban open space in the 21st century. Landscape and urban planning, 60(2), 59-72.

[24] Diamond, D.B., and Tolley, G.S. (Eds.) (2013). The Economics of Urban Amenities. Elsevier. from http://samples.sainsburysebooks.co.uk/ 9781483264752_sample_805888.pdf.

[25] Sullivan, W. C., \& Lovell, S. T. (2006). Improving the visual quality of commercial development at the rural-urban fringe. Landscape and urban planning, 77(1), 152-166.

[26] Oguz, D. (2000). User surveys of Ankara's urban parks. Landscape and Urban Planning, 52(2), 165-171.

[27] Wu, J., \& Plantinga, A. J. (2003). The influence of public open space on urban spatial structure. Journal of Environmental Economics and Management, 46(2), 288-309.

[28] Crow, T., Brown, T., \& De Young, R. (2006). The Riverside and Berwyn experience: Contrasts in landscape structure, perceptions of the urban landscape, and their effects on people. Landscape and Urban Planning, 75(3), 282-299.

[29] Yeang, Ken and Spector, Arthur (Ed.) (2011). Green Design: From Theory to Practice. United Kingdom, London: Black Dog Publishing.

[30] Yabes, R., Shetter, K., \& Schneeman, J. (1997). Urban waterways: changing historical uses and users in a southwestern desert city. Landscape and urban planning, 39(2), 167-185. 
[31] Özgüner, H., \& Kendle, A. D. (2006). Public attitudes towards naturalistic versus designed landscapes in the city of Sheffield (UK). Landscape and Urban Planning, 74(2), 139-157.

[32] Chiesura, A. (2004). The role of urban parks for the sustainable city. Landscape and urban planning, 68(1), 129-138.

[33] Lee, C. K., \& Mjelde, J. W. (2007). Valuation of ecotourism resources using a contingent valuation method: The case of the Korean DMZ. Ecological economics, 63(2), 511-520.

[34] Jim, C. Y., \& Chen, W. Y. (2007). Consumption preferences and environmental externalities: A hedonic analysis of the housing market in Guangzhou. Geoforum, 38(2), 414-431.

[35] Embong, A. R. (2011). Pembandaran dan kehidupan bandar di Semenanjung Malaysia. Akademika, 81(2), 23-39.

[36] Adamowicz, W., Louviere, J., \& Williams, M. (1994). Combining revealed and stated preference methods for valuing environmental amenities. Journal of environmental economics and management, 26(3), 271-292. 